\title{
Participatory Variety Selection for Enhanced Promotion of Improved Faba Bean Varieties in Konta and Tocha Districts of Southern Ethiopia
}

\author{
Yasin Goa Chondie*, Gezahagn Gr and Demelash Basa \\ Department of agriculture, Areka Agricultural Research Centre, Ethiopia
}

Submission: January 02, 2018; Published: April 06, 2018

"Corresponding author: Yasin Goa Chondie, Areka Agricultural Research Centre, SARI, Ethiopia, Email: yasingoac76@yahoo.com

\begin{abstract}
Present trials were executed in 2016/2017 in konta and Tocha districts in Southern parts of Ethiopia to assess the performance of faba bean varieties and to evaluate farmers' parameter for faba bean variety choice, and in so doing classify the principal farmers' criteria in the study site. Eight faba bean genotypes along with local check from respective area were evaluated in randomized complete block design with three replications in 2016/17 main cropping season. Farmers' assessment of faba bean was made at different stages of the crop, viz. at flowering, at maturity and at harvest. Farmers' proven; stand strength, tiller number, pod number, seed number, pod length, maturity, chocolate spot resistance, aphid resistance, seed size, leaf shading, seed color, straw yield and grain yield as preference parameters to test and ascertain their desired varieties. The analysis of variance results shown the presence of highly significant variation among test varieties for grain yield at probability level of 5\%. The maximum average grain yield was recorded from the genotypes Dosha (3581.8Kgha-1) and Bobicho-04 (3524.5kgha-1). Likewise, Bobicho-04, and Dosha were accepted as farmers' favorite varieties. Thus, these two varieties were selected for their field performance and from farmers' assessment standpoint. This study showed that farmers use a combination of traits when choosing a faba bean genotype for adoption and these should be considered in faba bean improvement. Therefore, varieties Dosha and Bobicho-04 were preferred for their superior grain yield performance and also appropriate from farmers' evaluation perspective. Thus these varieties can be recommended for cultivation under konta and Tocha areas and the innovative model farmers in the study areas would multiply the seeds of these varieties for better adoption and dissemination rate
\end{abstract}

Keywords: Faba bean; Replications; Farmers

\section{Introduction}

Faba bean (Vicia faba L.) is an important highlands pulse crop grown in Ethiopia at an altitude range between 1800-3000 masl, in place at the soil and weather are considered to be congenial for better growth and development of the crop. According to CSA [1], in Ethiopia about 443,107.88 hectares of land annually covered in Faba bean with estimated production of 8,389,438.97 quintals. In Ethiopia, faba bean is the leading source of protein for the small holder farmers and used to make a number of traditional dishes. Moreover, the crop is source of income for producers and foreign exchange for the country and also it can improve soil fertility through fixing atmospheric nitrogen [2]. It is a reliable source of income to the farmers, and earns foreign exchange to the country.

In SNNPR, Faba bean is cultivated in mid highland to highlands of the region occupies about $66,590.48$ hectares of land annually with estimated production of 1,091,411.71 quintals [1]. The regional (16.39qt/ha) average yield of faba bean has remained low [1]. Even though the crop has a number of potential uses, the productivity of the crop is far below the potential and is constrained by use of low yielding varieties, poor agronomic practices, prevalence of insect pests and diseases and declining of soil fertility. Therefore the present study geared to words identifying high yielding improved faba bean varieties adapted to the selected districts that are acceptable to farmers in study areas.

\section{Materials and Methods}

In the present investigation seven released faba bean varieties with local checks were evaluated in 2016/2017(2008/2009) at two AGP-II districts-Konta and Tocha (both in the Southern region) in Ethiopia. Two grandmother trials were laid at farmers field of Konta, Chaka Bocha (07006',125”N,036039'308”E) lies on the South region at an altitude 2101masl; while experimental farms of Tocha, Gada Mal Kebele (07005'421"N,037002'239"E) lies at 2632 meters above sea level. In each district, one location and at each location four farmers were identified to lay out the mother trials and one model farmer farm at each district were 
used for grandmother trials. The trials were designed by the researcher but laid and all cultural operations including planting, weeding and harvesting was managed by the selected farmers.

The genotype for the trials was composed of eight faba bean varieties namely Gabalicho, Degaga, Dosha, Tumsa, Bobicho-04, Moti, Angacha ${ }^{-1}$ and local check were conducted on farm in $2016 / 2017$ to seek farmer's preferences through PVS. The trials were arranged in randomized block design with three replications. Each variety was grown with a plot size of $6.4 \mathrm{~m}^{2}$ represented by 4 rows of 4 meter length with row and plant spacing of $40 \mathrm{~cm}$ and $10 \mathrm{~cm}$, respectively. Fertilizer rate and cultural practices were done as per national recommendation. Parameters such as grain yield and farmers' preferences data were collected for the faba bean varieties.

Invited participants were gathered at the host farmers' field to assess the faba bean varieties at flowering stage, at maturity and at harvest, assisted by scientists, assistants from Areka Research Center and agricultural experts from the Tocha and Konta Weredas Agriculture and Natural Resource development offices. Out of the 79 participants at districts 17 were women (22\%). During the evaluation farmers assembled to discuss what they thought were the important criteria for selecting a given variety at a particular development stages. Each criterion was scored from 1 to5 (1=Excellent, $2=$ very good, $3=$ moderate, $4=$ bad and $5=$ worst) for each variety. Participant farmers were also asked to give an overall score to each variety.

Farmers were selected among participants at each district to evaluate varieties from the PVS trials. Each of the randomly selected farmers were given eight faba bean varieties and oriented to manage all plots equally. Farmers assessed the varieties at flowering and maturity and at harvest. At maturity, farmers scored each variety for earliness, seed per pod, pods per plant; at harvest varieties were scored for seed size, grain color, straw yield and grain yield. Again, scores were given on a scale from 1 (excellent) to 5 (worst). At maturity and harvest, farmers were asked to give an overall assessment of each variety, using the same scale.

\section{Results and Discussion}

\section{Evaluation of researchers}

Researchers' evaluated the faba bean PVS trial at of konta district based on grain yield (Table 1). The varieties revealed a distinct statistical variation in grain yield and also there was significant difference among the faba bean varieties. As it is indicated in Table 1, Dosha has the highest grain yield 3581.8kgha ${ }^{1}$, but Angacha ${ }^{-1}(2577.6 \mathrm{~kg} / \mathrm{ha})$ was a variety with low grain yield [1-4]. In other words, the analysis result for PVS trial showed that there was significant difference among the varieties for grain yield at Konta in 2016/2017 (Table 1). Whereas in Tocha district, there were no yield data except farmers' preference scoring during field visit at flowering, maturity and at harvest stages due to prior harvesting and mixing up of the experiment by kebele development agent (Figure 1).

Table 1: Researchers' evaluation of 8 faba bean varieties in konta district in 2016/2017.

\begin{tabular}{|c|c|c|c|}
\hline Varieties & Gy (kg/ha) & $\begin{array}{c}\text { Researchers } \\
\text { Rank }\end{array}$ & Farmers rank \\
\hline Gabalicho & $2977.66 b c$ & 5 & 4 \\
\hline Degaga & $2990.66 b$ & 4 & 2 \\
\hline Dosha & $3581.8 \mathrm{a}$ & 1 & 3 \\
\hline Tumsa & $3074.2 \mathrm{~b}$ & 3 & 5 \\
\hline Bobicho-04 & $3524.5 a$ & 2 & 1 \\
\hline Moti & $2936.2 b c$ & 6 & 6 \\
\hline Angacha-1 & $2577.1 d$ & 8 & 8 \\
\hline Local & $2640.6 \mathrm{~cd}$ & 7 & 7 \\
\hline G.mean & 3077.8 & & \\
\hline $\operatorname{LSD}(0.05)$ & 348.5 & & \\
\hline $\mathrm{CV}$ & 9.78 & & \\
\hline
\end{tabular}

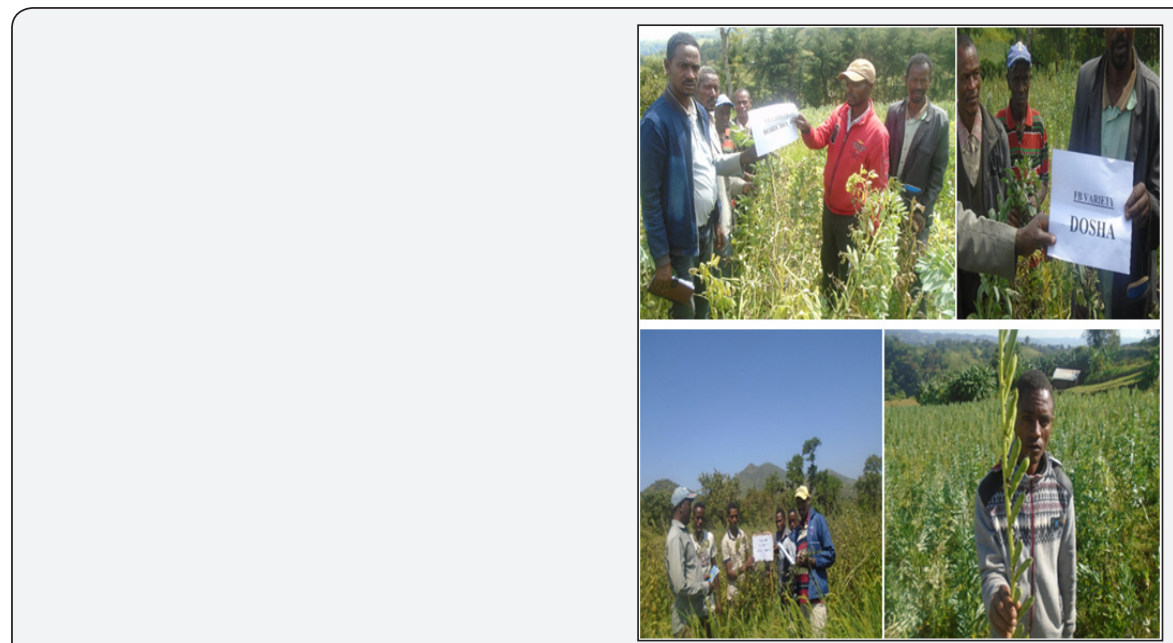

Figure 1: Evaluation of faba bean varieties by farmers and concerned stakeholders. 


\section{Farmers variety evaluation}

Representative farmers from the study area were participated and evaluated the PVS trial. The evaluated farmers were most interested in some of the parameters like stand strength (lodging resistance), branch number/tillers, number of pod, number of seed, length of pod, maturity, chocolate spot resistance, aphid resistance, size of seed, leaf shading, seed color, straw yield and grain yield (Table 2). When evaluating faba bean genotypes for adoption, out of the fourteen different traits farmers chose traits that they often use. Therefore, while farmers consider many traits, there are a few traits that they often use and these need to be identified. Earlier studies by Gurumu [3] working on common bean and Wondimu [4] working on faba beans reported similar findings of farmers using a combination of a few traits when evaluating new genotypes. At flowering, maturity stage and at harvest, the farmer evaluated PVS trials at Konta and Tocha, generally farmers responded positively to the faba bean varieties they have assessed. In the study faba bean varieties farmers evaluation showed that there was a matching with researchers need. Moreover, farmers evaluations and testing farmers field both show variance. Table 2 Farmers' entire evaluation indicate that variety Bobicho-04, Dosha, Degaga, Gabalico and Moti were the top from the test faba bean varieties. The Angacha ${ }^{-1}$ variety have showed poor performance and least preferences by farmers in most cases.

Table 2: Faba bean varieties selection criteria $n=79$ (male=62 Female=17) used by farmers and their assessment in two districts, ranked in order of importance.

\begin{tabular}{|c|c|c|c|c|c|c|c|c|}
\hline \multirow[t]{2}{*}{ SCS } & \multicolumn{8}{|c|}{ Fabe Bean Varieties } \\
\hline & Bobicho & Dagaga & Tumsa & Moti & $\begin{array}{c}\text { Angacha } \\
-1\end{array}$ & Gabalcho & Dosha & Local \\
\hline \multicolumn{9}{|c|}{ Konta District } \\
\hline Stand strength & 1 & 5 & 4 & 3 & 4 & 3 & 3 & 3 \\
\hline Branch number/tillers & 3 & 1 & 4 & 5 & 4 & 4 & 4 & 2 \\
\hline Pod number & 4 & 1 & 2 & 2 & 2 & 2 & 2 & 3 \\
\hline Seed number & 1 & 1 & 4 & 1 & 4 & 4 & 4 & 3 \\
\hline Pod length & 1 & 1 & 2 & 2 & 2 & 2 & 2 & 1 \\
\hline Maturity & 1 & 1 & 1 & 3 & 1 & 1 & 1 & 2 \\
\hline Chocolate spot resistance & 1 & 1 & 4 & 3 & 4 & 4 & 4 & 2 \\
\hline Rust resistance & 1 & 5 & 2 & 2 & 2 & 2 & 2 & 3 \\
\hline Aphid resistance & 2 & 1 & 2 & 3 & 2 & 2 & 2 & 2 \\
\hline Seed size & 1 & 2 & 1 & 3 & 1 & 1 & 1 & 2 \\
\hline Leaf shading (manure) & 1 & 2 & 2 & 1 & 2 & 2 & 2 & 1 \\
\hline Seed Color & 1 & 1 & 1 & 1 & 1 & 2 & 1 & \\
\hline grain yield & 4 & 3 & 3 & 4 & 5 & 1 & 1 & 8 \\
\hline Straw yield & 3 & 2 & 3 & 1 & 5 & 2 & 2 & 5 \\
\hline \multicolumn{9}{|c|}{ Tocha District } \\
\hline Stand strength & 2 & 4 & 4 & 4 & 4 & 3 & 1 & 3 \\
\hline Branch number/tillers & 1 & 4 & 4 & 4 & 4 & 5 & 3 & 2 \\
\hline Pod number & 1 & 2 & 2 & 2 & 2 & 2 & 3 & 3 \\
\hline Seed number & 1 & 4 & 4 & 4 & 4 & 1 & 1 & 3 \\
\hline Pod length & 1 & 2 & 2 & 2 & 2 & 2 & 1 & 3 \\
\hline Maturity & 2 & 1 & 1 & 1 & 1 & 3 & 1 & 2 \\
\hline Chocolate spot resistance & 1 & 4 & 4 & 4 & 4 & 3 & 1 & 2 \\
\hline Rust resistance & 3 & 2 & 2 & 2 & 2 & 2 & 1 & 3 \\
\hline Aphid resistance & 1 & 2 & 2 & 2 & 2 & 3 & 2 & 2 \\
\hline Seed size & 2 & 1 & 1 & 1 & 1 & 3 & 1 & 2 \\
\hline Leaf shading (manure) & 2 & 2 & 2 & 2 & 2 & 1 & 1 & 1 \\
\hline Seed Color & 1 & 1 & 2 & 1 & 1 & 1 & 1 & 1 \\
\hline grain yield & 3 & 1 & 1 & 3 & 5 & 4 & 2 & 4 \\
\hline Straw yield & 2 & 2 & 2 & 3 & 5 & 1 & 3 & 5 \\
\hline
\end{tabular}




\begin{tabular}{|c|c|c|c|c|c|c|c|c|}
\hline Overall sum & 48 & 59 & 68 & 69 & 78 & 66 & 53 & 73 \\
\hline average & 1.71 & 2.11 & 2.43 & 2.46 & 2.79 & 2.36 & 1.89 & 2.61 \\
\hline Rank & 1 & 3 & 6 & 5 & 8 & 4 & 2 & 7 \\
\hline
\end{tabular}

Generally farmers of both target districts selected faba bean variety Bobicho-04, Dosha, Degaga, and Gabalicho as $1^{\text {st }}$, $2^{\text {nd }}, 3^{\text {rd }}$ and $4^{\text {th }}$. The Angacha ${ }^{-1}$ variety have indicated inferior performance in most cases and rejected by participant farmers (Table 2). NB: Overall Score: (1-5) Scale; 1=Excellent, 2=Very Good 3=moderate, 4=bad and 5=worst; Where, SCS=selection criteria set by farmers.

\section{Conclusion}

The most preferred genotypes identified by the focus group discussion through PVS and researchers analysis result were Dosha and Bobicho-04. These genotypes need to be demonstrated on big plot size in pre-extension demonstration (PED) and finally to recommend the varieties for up scaling through participatory seed production. The first two varieties (Dosha and Bobicho-04) were also identified by Researcher as the most preferred varieties for yield and other desirable traits. The study indicates that to assure the quality and quantity of data enough resources have to be made available to capacitate experts and farmers at grass root level in future.

\section{Recommendations}

From the findings, we need to carry out:

1. Promotion of good agricultural practices and preferred faba bean varieties in trials implemented sites.

2. Designing seed multiplication and distribution technique to make seeds of these varieties sustainability available to farmers.

\section{Acknowledgement}

The authors would like to thank farmers for their cooperation and for providing land for laying out PVS trials and their whole hearted participation in the evaluation of faba bean varieties. We also thank Areka Research Center technical staffs namely Ato Tadel Hirgo, Ato Denekae Makae, W/rt Bogalech Uta and Ato Filimon Uliso for the field data collection and close follow up. Furthermore we are grateful to South Agricultural Research Institute for providing fund for conducting this work is duly acknowledged.

\section{References}

1. CSA (Central Statistical Agency of the Federal Democratic Republic of Ethiopia) 2014/15. Agricultural Sample Survey, 2014/15. Report on Area and production of major crops (Private Peasant Holdings, meher season). Statistical Bulletin, Addis Ababa, Ethiopia 278(1).

2. Desta Beyene (1988) Biological nitrogen fixation research on grain legumes in Ethiopia. In: Bec DP, Materons LA (Eds.), Nitrogen Fixation by Legumes in Mediterranean Agriculture. ICRADA, Marthinus Nizhoff, Dordrecht, Boston 32: 73-78.

3. Gurmu F (2013) Assessment of Farmers Criteria for Common Bean Variety Selection: The case of Umbullo Watershed in Sidama Zone of the Southern Region of Ethiopia. Ethiopian E-Journal for Research and Innovation Foresight 5: 4-13.

4. Bekele W (2016) Participatory variety selection of Faba Bean for yield components and yield at highlands of West Hararghe, Eastern Ethiopia International Journal of Plant Breeding and Crop Science 3(1): 099102. 